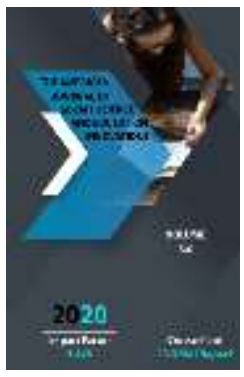

Journal Website: http://usajournalshub.c om/index,php/tajssei

Copyright: Original content from this work may be used under the terms of the creative commons attributes 4.0 licence.

\section{The Rubai Genre In The Works Of Jamal Kamal}

\section{Dilrabo Quvvatova}

Ph.D, Professor Of Department Of Uzbek Literature, Bukhara State University, Bukhara, Uzbekistan

\section{Dildora Nazarova}

Assistant Of Department Of Uzbek Language And Literature, Bukhara State Medical Institute, Bukhara, Uzbekistan

\title{
ABSTRACT
}

It is known that rubai is a common lyrical genre in the literature of the peoples of the East. This artistic development was achieved in the works of classical poets such as Umar Khayyam, Pahlavon Mahmud, Alisher Navoi, Babur, Ogahi, Munis.

\section{KEYWORDS}

Lyrical genre, classical poets, literary critic, rubai, literary theory, khose rubai, taronai rubai.

\section{INTRODUCTION}

Well-known literary critic E. Ochilov writes about this in his fundamental study "Rubai in Uzbek literature":

In modern Uzbek poetry, the tradition of rubai writing has been successfully continued in the works of such poets as M. Shaykhzoda,
Shuhrat, J. Kamal, Ramz Bobojon, M. Kenjabek. Consequently, works in the rubai genre play an important role in Jamal Kamal's poetry. 


\section{LITERATURE REVIEW}

The main factor in the strong position of this genre in the work of the poet is, firstly, his good knowledge of Oriental literature, and secondly, the translation of Umar Khayyam, Ibn Sino, Baba Tahiri Uryan rubai from Persian Tajik into Uzbek. The process of translation had a great influence on the poet's artistic rise. It can be said that the universal ideas and views in the works of the great rubai writers were also reflected in the rubai of J. Kamal.

It is known from literary theory that the rubai has its own strict weight and is written in the ahram and akhrab trees of the hazaj bahri. These trees consist of 24 parts. In addition, the rubai is rhymed in two ways: if it is in the form of a-a-b-a, it is khose rubai; if rhymed as a-a-a-a, it is called taronai rubai.

\section{ANALYSIS}

There are both versions of the rubai in Jamal Kamal's work. Including:

It's an honor, I want to,

(Ul sho-nu / sha-raf-ki, ma / -nu man is-tar / man,)

I would like a rose petal, (Gul-bar-ra / -vu bar-gi yo / -su-man is-tar / man.)

I'd like flowers in the garden,

(Bog' ich-ra / che-chak-lar-ni / cha-man is-tar / man,)

I want to heart the homeland.

(El ich-ra / va-tan-lar-ni / yu-rak is-tar / -man.)

Maf-uv-lu / ma-fo-iy-lun / ma-fo-iy-lun / fa'

The above rubai hazaji musammani ahram is written in abtar weight. Irrigated with the spirit of vitality, this rubai expresses the lyrical hero's desire to achieve self (manu man istash). The poet sees his identity in an open bag in the garden.

You will have a pure heart in the heart of the country,
(Yurt ko'k-si / -da to-za bir / yu-rak bo'l-gay / sen,)

You will be a pillar for nation's happiness

(El bax-ti-ga / tog' ka-bi tir / -gak (i) bo'l-gay / sen)

Be patient and keep your faith healthy

(Sabr ay-la / -yu iy-mon-ni / sa-lo-mat saq / -la,)

One day you will be needed in this country

(Bir kun shu / va-tan-ga ke / -rak (i) bo'l-gay / sen.)

Maf-uv-lu / ma-fo-iy-lun / ma-fo-iy-lun / fa'

The above rubai is also written in the Hazaji musammani ahram abtar weight. It reflects on the duty of childhood to the country. "Pure heart in the heart of the country" is an artistic invention of the poet.

This is the first condition that the country needs. "To be a pillar of nation's happiness " is the next condition to be a worthy child. In addition, patience and keeping the faith healthy are good deeds for becoming a child of the country. Such life content is embedded in the verses of the rubai.

It is a centuries-old literary tradition that in classical poetry the rubai are also written on the theme of love. Jamal Kamal also creatively continued this tradition. His rubai on the subject of love confirm our views:

O flower, your flower is so clear

(Ey gul, gu / -ling, ta-ro-va / -ting mun-cha / tiniq,)

The fondness in the garden is so clear (Bog' (i) ich / -ra la-to-fa / -ting bun-cha / ti-niq.) Maf-uv-lu / ma-fo-iy-lu / maf-uv-lu / fa-al In the morning you will have a handful of silver (Tong qo'y-ni/-da bir hovuch/ ku-mush tal'/-atsen,)

Morning star, your morning thaw is so clear (Tong yul-du / -zi, tong-gi tal' / -a-ting mun-cha / ti-niq [253].)

Maf-uv-lu / ma-fo-iy-lun / ma-fo-iy-lun / fa-al 
The ruby weight above is peculiar. Created in two different weights at the same time. The first two verses of the hazaji musammani ahrami makfufi ajab are written in weight, and the next two verses are written in the weight of the hazaji musammani axrami ajab.

This is also a characteristic feature of the poet's style. The flower is a metaphor and represents a beloved lover. The poet sees the beauty of the mistress in its freshness, grace, in the purity of the morning. "A handful of silver thaw" is a poetic invention of the poet, a difficult metaphor applied to a lover. Consequently, it is based on the whiteness of the morning. "Silver Thaw" means a white face. Khose Rhyme as a rubai in the form of aaba (tarovating, latofating, tal'ating).

I had a wonderful dream last night, (O't-gan ke / -cha uy-qum-da / a-jib tush / ko'r$\operatorname{dim}$, )

I liked the moon piece face again.

(Oy par-cha / -si cheh-rang-ni / ya-na xush / ko'r-dim.)

You were a bride with a silk scarf on your head,

(Bo-shing-da / ha-rir ro'-mol /, ke-lin-chak / erding,)

I found myself unconscious again in front of you

(Qar-shing-da / ya-na o'-zim / -ni be-hush / ko'rdim... [267])

Maf-uv-lu / ma-fo-iy-lun / ma-fo-yil / fa'-lun

This rubai is written in hazaji musammani ahrami maksuri aslam weight. In the rubai, the beautiful face of the sweetheart resembles a piece of the moon. The mistress herself is described as a "bride in a silk scarf." In these images, the lyrical protagonist expresses his love for his lover.

She is a gentle valentine walker, a stander, (UI noz-li / ni-gor yur-gu / -si-dur, tur-gu / -sidir,)
It's a pain in the ass, a laugh.

(Jo-nim-ga / si-tam g'am-za / -si-dir, kul-gu / -sidir.)

Shake like a sambit, idol, laugh, idol,

(Sam-bit ka / -bi sil-kin-ma /, sa-nam, kul-ma, / sa-nam,)

Your laugh kills me every moment.

(Kul-ging me / -ni har lah-za/-da o'l-dir-gu / -si$\operatorname{dir}[268]$.)

Mav-uv-lu / ma-fo-iy-lun / ma-fo-iy-lun / fa-al

The above rubai is written in hazaji musammani ajabb weight. In this rubai, the beloved is described as a beautiful "flirtatious valentine." Her looks, her laughter hurt the soul of the lover. The walk of the lover is like a sambit, his laughter, her smile kills the lover at every moment, that is, she kindles love in his heart.

Apparently, the poet's rubai on the theme of love, first of all, have a special artistic content due to their tradition, as well as their richness of difficult assimilation and metaphors.

Jamal Kamal's rubai drank water from the sources of Eastern poetry. Therefore:

Give me a breath of the smell of Bukhara, (Ber-gil me / -nga bir na-fas Bu / -xo-ro bo'-yidin,)

Pour me a cup of Bukhara water,

(Qo'y-gil me / -nga bir ko-sa Bu / -xo-ro su-yidin,)

O man of the garden,

(Ey bo-g'u / cha-man-lar ko' / -yi da er-ka sabo,)

Bring me a bass from Bukhara

(Kel-tir me / -nga bir na-sim / Bu-xo-ro ku / -yidin... [257])

Maf-uv-lu / ma-fo-iy-lun / ma-fo-iy-lu / fa-al

This rubai, written in the weight of the hazaji musammani makfufi ajabb, is reminiscent of the lines of the great Rudaki, which begin with the words “Bo'yi jo'yi Mo'liyon oyad hame” 
and run with feelings of burning love for the Motherland. In particular, such images as "Buxoro bo'yi(Bukhara neck)", "Buxoro suyi(Bukhara water)", "Buxoro kuyi(Bukhara song)" confirm this.

After all, Bukhara is the birthplace of the poet. The country that introduced him as a poet is the great Tashkent. While living in Tashkent, he felt a great love for Bukhara. That is why the whole of Bukhara, the pure fragrances coming from this direction, feel thirsty for the water of Bukhara. He wants the people of this country to report on Bukhara.

Another distinctive feature of the poet's rubai is that they are imbued not only with a moralphilosophical content, but also with a social spirit. This can be assessed as a renewal of the poet's poetic thinking. Therefore, the rubai on the theme of independence confirm our views:

Let everyone be independent

(Har kim-sa-yu kas-da mus-ta-qil-lik bo'l-sin,)

May every dream be independent.

(Har or-zu-yu ha-vas-da mus-ta-qil-lik bo'l-sin.) Step by step independence in each new step, (Har yan-gi qa-dam-da mus-ta-qil-lik-da qadam,)

Let there be independence in every clean breath... [256]

(Har to-za na-fas-da mus-ta-qil-lik bo'l$\sin . . .[256])$

It is known that this rubai was written in the first years of independence. At the same time, independence was combined with the notion of freedom. The poet feels this in the independent action of each person, in the air of dreams, in every step, in every breath he takes.

My people, it's your turn again, build a state (Xal-qim, ya / -na yet-di nav / -ba-ting, dav- / lat qur,)
Show your strength again, build a state.

(Ko'r-sat ya / -na kuch-ma-to / -na-ting, dav / lat qur.)

Your happiness is great in the world, build a state,

(Dun-yo-da / bu-yuk sa-o / -da-ting, dav / -lat qur,)

No matter what your state is, build a state

(Har ne / -ki bo'l-sa dav / -la-ting, dav / -lat qur [260].)

Maf-uv-lu / ma-fo-iy-lun / ma-fo-yil / fa-al

The above rubai, written in hazaji musammani ahrami makfufi ajabb weight, is a logical continuation of the rubai we have analyzed. The verses written as an appeal to the people reflect the glory of our independence. The poet calls the people's perseverance and independence "the greatest happiness in the world."

An important genre feature of the rubai is that it conveys the cream of vital philosophical ideas and thoughts. J. Kamal's rubai are also traditional in this respect. In particular, the interpretation of life plays an important role in the classical poetry of the East. The following narration of Umar Khayyam is important in this regard:

We came clean, we were dirty cause of vexation.

(Pok kel-ga / -n e-dik a-lam / -din, no-pok / bo'ldik.)

We arrived at the door happy and be sad.

(Sho-don ye / -ti-shib e-shik / -ka, g'am-nok / bo'l-dik.)

We passed the fire of the tongue, with tears, (O't-dik ba / -se dil o-ta / -shi, ko'z yosh / bi-la,)

We have given this life to the nation and be the dust (285).

(Ber-dik shu / umr-ni el-ga / -yu hok (i) / bo’l-dik (285).)

Maf-uv-lu / ma-fo-yi-lun / maf-uv-lun / 
According to the poet, man becomes pure in the world, but becomes polluted in this world. The "door" represents the world. Human life passes with heartburn, tears, that is, joy and anxiety. The rapid passage of life is compared to the wind. To be "be dust" is to leave this world. In this rubai of Jamal Kamal, a similar interpretation is observed:

O Lord, I am your slave, I am the living soil [life]

(Yo Rab, se / -nga ban-da-man /, ti-rik tup / roq-man [umr])

One day less, the next day more.

(Bir kun ka / m e-sam, er-ta / -si kun ko'p / -roqman.)

Don't let the wind blow so hard, don't shake so much

(Shid-dat bi / -lan es-ma, bun / -cha sil-kit-ma /, sha-mol,)

I have a green leaf on a tree

(An-vo-yi / da-raxt-ga bi / r (i) ya-shil yap / -roqman... [257])

Maf-uv-lu / ma-fo-iy-lun / ma-fo-iy-lu /

\section{DISCUSSION}

It should be noted that J. Kamal continued the tradition. That is, life is like the wind. At the same time he renewed his poetic thought. So the "tree" is the world of light, and the green leaf is the person in it. In addition, it stands firmly on the green leaf band. In this sense, this image represents the youth of man. That is why the lyrical protagonist does not want the wind to blow fast, that is, life to pass quickly. Indeed, in the rubai, man's life in the light world is likened to a "living soil", a "green leaf", which is the result of the poet's deep observations about life.

In the rubai of Umar Khayyam, it is said that life is the transience of the world, so it should not be wasted:

If Ayyomi is alive,
(Ayyomi tiriklikdan agar on o'tsin,)

Let him rejoice and be glad.

(Azm aylaylik, ul xurrami shodon o'tsin.)

After all, capital is the property of the world.

(Zinhorki, sarmoyayi bu mulki jahon-)

Let life pass, let it pass uza [286]

(Umr emish, ul ham guzaron - o'tsin... [286])

According to Umar Khayyam, it is a holiday of life. However, it should be celebrated with joy and determination. According to the poet, "capital is the property of the world" is life. Man is unaware that he has passed. The following rubai of Jamal Kamal echoes this:

This anxiety will inevitably pass,

(Bu tash-vish-u g'al-va be-gu-mon o't-gu-si-dir,) Without imagining the past, it still goes.

(O't-gan-da ha-yalla-may, ha-mon ket-gu-sidir.)

Dear friends, with measures and means

(Ey do's-tu yo-ron-lar, cho-ra-i tad-bir ila)

Time to reach your dream destination... [258] (Or-zu-da-gi man-zil-ga za-mon yet-gu-si-dir... [258])

"It's a worry" is a person's life, it will pass.

Therefore, in order to reach the "dream destination", it is necessary to appreciate it, says the poet.

Apparently, Jamal Kamal, as a translator of the rubai, incorporated their noble thoughts and ideas into his rubai as well. It can be said that J. Kamal's rubai can be compared to classical rubai not only in form but also in content.

It can be observed that Jamal Kamal's rubai were in harmony with the rubai of Navoi and Babur. The following rubai of Navoi on the theme of love is a proof of our opinion:

I love you dear, dear life, (Jondin seni ko'p sevarmen, ey umri aziz) So I love you so much, dear life. (Sondin seni ko'p sevarmen, ey umri aziz) 
No matter how much you love,

(Har neniki sevmak ondin ortuq bo'Imas)

I love you so much, dear life.

(Ondin seni ko'p sevarmen, ey umri aziz)

\section{In Bobur:}

You are my life

(Jonimdan mening hayoti jonim sensen)

You are my soul in my body,

(Jismimdan mening ruhu ravonim sensen)

Bobur's half as dear as you,

(Boburning seningdek yo'q yori aziz)

You are my eternal life.

(Alqissaki, umri jovidonim sensen.)

\section{In Jamol Kamal:}

If you only knew I was in love with nibs, (Lutfing-la suyukligimni sen bilsang edi)

If only you knew how great I am with lovingly.

(Mehring-la buyukligimni sen bilsang edi)

Burn in the fire you love, O soul,

(Yoqqan olovingda o'rtanib, ey jon)

If only you knew I was hot every

moment...[273]

(Har lahza quyuqligimni sen bilsang edi)

The three rubai themes above are proportional in content. First of all, the theme of love connects these three rubai. In addition, the unity of the image, that is, "you" is united by the image of the lover, which is reflected in the personal pronoun of the second person. At the same time, in Navoi "dear life", in Babur "life is soul", "soul is flowing", "life is eternal", in J. Kamal "life" are more welldefined metaphors of this image. This justifies Jamal Kamal's legacy to the literary tradition. In addition, the lyrical protagonist feels love in the words and kindness of the lover.

The lover burned in the fire of his love. Consequently, the words "my love(suyukligim)", "my greatness(buyukligim)", "my warmth(quyuqligim)", which provide harmony in the rubai, also served to express the poetic content.

Another rubai of Jamal Kamal, Babur, recalls the melodies of the following rubai:

A person in a foreign country who does not remember breastfeeding,

(Yod et-ma / s e-mish ki-shi / -ni g'ur-bat-da / kishi,)

Breastfeeding is a person who works hard.

(Shod et-ma / s e-mish ko'-ngul / ni meh-nat-da / ki-shi.)

My heart did not rejoice at this strangeness, oh,

(Ko'nglim bu / g'a-rib-lik / shod- (i) o'l-ma / -di, oh)

Of course, it's not fun to be abroad

(G'ur-bat-da / se-vun-ma -s e / -mish, al-bat-ta /, ki-shi)

Maf-uv-lu / ma-fo-iy-lu / ma-fo-iy-lu / fa-al

In Jamol Kamal:

If God don't remember you, who will make you happy?

(Yod et-ma/-sa Haq, kim se/-ni shod ay/-lar?)

If God are not happy you, who will make you happy?

(Shod et-ma/-sa Haq, kim se/ni shod ay/-lar)

You find God in this bright world

(Sen Haqqa/ to-pin-gil, shu/ yo-rug' dun-yo/-da)

Oh God, if you do not say, who will cry out to you

(Yo Haq, de/-ma-sang, kim sen/-ga far-yod ay/lar?[264])

Maf-uv-lu / ma-fo-iy-lun / ma-fo-iy-lun / fa'

These two rubai forms correspond to each other. The first two lines start almost the same. The first rubai describes Bobur's sufferings in exile. Jamal Kamal's rubai reflects the idea of remembering and worshiping Allah. 


\section{CONCLUSION}

It can be said that Jamal Kamal was influenced by Babur's rubai and followed them at a glance. At the same time, the poet's unique poetic way of thinking is reflected in the artistic interpretation. That is, religious mystical sources are taught that in order to purify the soul, one must remember the Creator. This reveals the innovative nature of the poet's work.

\section{REFERENCES}

1. Dildora Nazarova The interpretation of educational ideas in the poems of Jamal Kamal SOI: 1.1/TAS DOI: 10.15863/TAS International Scientific Journal Theoretical \& Applied Science p-ISSN: 2308-4944 (print) e-ISSN: 2409-0085 (online) Year: 2019 Issue: 11 Volume: 79 Published: 20.11.2019 http://T-S, 136-138

2. Dildora Nazarova Literary Motives of Sufizm and Spiritual, Moral Ideas in the Lyrics of Jamal Kamal International Journal of Recent Technology and Engineering (IJRTE) ISSN: 2277-3878, Volume-8, Issue-3S, October 2019, 223225.

3. Poetry of Jamal Kamal D Nazarova Scientific Bulletin of Namangan State University 1 (7), 86-89 2019 ISSN 2181-0427

4. Гафуров Б.3. Сравнительное изучение сегментных фоновариантов существительных русского, узбекского и английского языков, различающихся изменением фонемного состава // Современные гуманитарные исследования. - М., 2009. - № 6. - С. 127-129.

5. Gafurov B.Z. Comparative study of segmental phonovariants of nouns in
Russian, Uzbek and English, differing in the change in the phonemic composition // Modern humanitarian research. - M., 2009. - No. 6. - S. 127-129.

6. Gafurov B.Z. Analysis of the relationship of medical terminology with segment phonostylistics of the noun in russian, uzbek and English languages // Theoretical \& Applied Science. International Scientific Journal. Philadelphia, USA, 2020.- № 1 (81). - P. 464-466. http://T-Science.org Гафуров Б.3. «К» ундош харфи билан бошланадиган ўзбек тилидаги отлар фоностилистикаси татқиқоти // Научный вестник НамГУ. - Наманган, 2019. -№6.Б. 272-275. Gafurov B.Z. Research of phonostylistics of horses in the Uzbek language beginning with the consonant letter "K" // Научный вестник NamGU. Namangan, 2019. -№6.- pp. 272-275.

7. Yuldasheva Dilorom, Ashurbayeva Ruqiya, Asadova Shakhlo "Use of an Integrative Research on the Education System" International Journal of Recent Technology and Engineering (IJRTE) ISSN: 2277-3878, Volume-8 Issue-4, November 2019

8. Ashurbayeva R.Q. THE CONCEPT OF INTEGRATION AND ITS APPLICATION IN EDUCATION SOI: 1.1/TAS DOI: 10.15863/TAS International Scientific Journal Theoretical \& Applied Science pISSN: 2308-4944 (print) e-ISSN: 24090085 (online) Year: 2020 Issue: 02 Volume: 82 Published: 21.02.2020 http://TScience.org.

9. Bozorov Z.A.The system of formation of civic culture among students in higher educational institutions ISJ Theoretical \& Applied Science, 01 (81), 455-458. Soi: http://s-o-i.org/1.1/TAS-01-81-81 Doi: https://dx.doi.org/10.15863/TAS Scopus ASCC: 3304. (2020). 
Doi: https://doi.org/10.37547/tajssei/Volume02Issue09-53

10. Zahiriddin Muhammad Bobur. Devon. Tashkent: Fan, 1994. p. 96. 